\title{
UJI PENYEMBUHAN LUKA SAYAT EKSTRAK ETANOL BUAH KECOMBRANG (Etlingera elatior Jack.) TERHADAP TIKUS PUTIH
}

\author{
Grace Anastasia Br. Ginting1, Vivi Asfianti2,", Modesta Harmoni Br. Tarigan ${ }^{3}$ \\ ${ }^{1}$ Universitas Sari Mutiara Indonesia, Medan, Indonesia \\ ${ }^{2,3}$ Fakultas Farmasi dan Ilmu Kesehatan, Medan, Indonesia \\ Email: vivi.asfianti@yahoo.com \\ *Corresponding author
}

\begin{abstract}
Abstrak
Kecombrang (Etlingera elatior Jack.) merupakan tumbuhan dari famili Zingiberaceae secara tradisional biasa digunakan oleh masyarakat Sumatera Utara sebagai bahan masakan, peningkat kuantitas Air Susu Ibu (ASI) serta sebagai obat luka. Kecombrang memiliki kandungan flavonoid, saponin, tanin, dan asam fenolat yang mampu memberikan efek antibakteri. Tujuan penelitian ini yaitu uji penyembuhan luka sayat ekstrak etanol buah kecombrang (Etlingera elatior Jack.) terhadap tikus putih. Penelitian ini merupakan eksperimental dan dilakukan di laboratorium Fakultas Farmasi dan Ilmu Kesehatan, Universitas Sari Mutiara Indonesia, Serbuk simplisia buah kecombrang dikarakterisasi dan diskrining fitokimia kemudian diekstraksi secara maserasi dengan etanol 96\%. Ekstrak diberikan secara topikal dalam 3 konsentrasi yaitu 8\%, 10\%, dan 12\% dalam bentuk sediaan salep. Ekstrak diujikan terhadap luka sayat sepanjang $2 \mathrm{~cm}$ pada punggung tikus putih. Kontrol positif yang digunakan adalah Betadine salep 10\%, sedangkan kontrol negatif hanya dilukai saja dan diberikan basis salep. Hasil penelitian menunjukkan bahwa ekstrak etanol kecombrang dapat menyembuhkan luka sayat terhadap tikus putih dan dengan konsentrasi $12 \%$ sama efektifnya dengan kontrol positif terhadap penyembuhan luka sayat yakni pada hari ke-10.
\end{abstract}

Kata kunci: Penyembuhan luka; Luka sayat; Kecombrang; Skrining fitokimia

\begin{abstract}
Kecombrang (Etlingera elatior Jack.) is a plant from the Zingiberaceae family which is traditionally used by the people of North Sumatra as a cooking ingredient, increasing the quantity of breast milk and as a wound medicine. Kecombrang contains flavonoids, saponins, tannins, and phenolic acids that can provide antibacterial effects. The purpose of this study was to test the wound healing of the ethanol extract of the kecombrang fruit (Etlingera elatior Jack.) on white rats. This research is experimental and was carried out in the laboratory of the Faculty of Pharmacy and Health Sciences, Sari Mutiara University, Indonesia. The Kecombrang fruit simplicia powder was characterized and screened for phytochemicals and then extracted by maceration with $96 \%$ ethanol. The extract was administered topically in 3 concentrations, namely $8 \%, 10 \%$, and $12 \%$ in the form of an ointment. The extract was tested against a $2 \mathrm{~cm}$ long cut on the back of a white rat. The positive control used was Betadine ointment 10\%, while the negative control was only injured and given ointment base. The results showed that kecombrang ethanol extract was able to heal cuts on white rats and with a concentration of $12 \%$ it was as effective as a positive control on wound healing on the 10th day.
\end{abstract}

Keywords: Wound healing, Cut wound, Kecombrang, Phytochemical screening 


\section{PENDAHULUAN}

Luka adalah rusak atau hilangnya jaringan tubuh yang terjadi karena adanya faktor yang mengganggu sistem perlindungan tubuh. Bentuk luka tergantung dari penyebabnya ada yang terbuka ada yang tertutup. Salah satu contoh luka terbuka adalah luka sayat/insisi dimana terdapat robekan linier pada kulit dan jaringan di bawahnya (Gemy, et.al., , 2015). Obat luka salah satunya dapat diberikan sediaan obat dalam bentuk salep. Salep merupakan salah satu bentuk sediaan farmasi pada kulit sehat, sakit atau terluka dimaksudkan untuk efek topikal. Salep digunakan untuk mengobati penyakit kulit kronis atau akut, sehingga diharapkan adanya penetrasi ke dalam lapisan kulit agar dapat memberi efek yang diinginkan. Suatu obat dalam bentuk sediaan salep untuk dapat mencapai efektivitas yang maksimum dari bentuk sediaan salep, maka perlu dipelajari mengenai struktur kulit dan formulasi sediaan dengan baik, seperti pemilihan bahanbahan pembawa atau basis, karena pembawa akan mempengaruhi pelepasan zat aktif dan absorpsinya pada lapisan kulit (Soegihardjo, 2013). Oleh karena itu, salah satu alternatif adalah penggunaan bahan alam dalam pembuatan salep, salah satunya adalah pemanfaatan buah kecombrang.

Kecombrang (Etlingera elatior Jack.) merupakan salah satu tumbuhan tradisional. Tumbuhan ini di daerah Sumatera Utara biasa disebut dengan kecombrang (Medan) dan kincung (Berastagi). Tumbuhan ini biasanya digunakan sebagai bahan masakan oleh masyarakat, peningkat kuantitas Air Susu Ibu (ASI) dan sebagai obat luka. Tumbuhan kecombrang mengandung zat aktif seperti flavonoid, saponin, dan polifenol (Gemy, et.al., 2015). Sebelumnya telah dilakukan penelitian tentang penyembuhan luka sayat ekstrak etanol daun kecombrang (Etlingera Elatior Jack) dalam sediaan gel terhadap kelinci (Gemy et.al., 2015). Potensi buah sebagai penyembuh luka belum pernah dikaji, berdasarkan uraian tersebut, dilakukan penelitian uji penyembuhan luka sayat ekstrak etanol buah kecombrang (Etlingera elatior Jack.) terhadap tikus putih.

\section{METODE PENELITIAN}

Penelitian ini dilakukan secara eksperimental dengan tahapan penelitian yaitu pengumpulan dan pengolahan sampel, pembuatan simplisia, pembuatan ekstrak, pembuatan salep, uji terhadap penyembuhan luka, perhitungan diameter luka dan analisa statistika.

\section{Lokasi Penelitian}

Penelitian ini dilakukan di laboratorium Fakultas Farmasi dan Ilmu Kesehatan, Universitas Sari Mutiara Indonesia pada bulan Juli - Agustus 2019.

\section{Alat dan Bahan}

Alat-alat yang digunakan meliputi sarung tangan hewan, masker, baju lab, bungkus kepala, alat freeze dryer, aluminium foil, blender, cawan porselen, cottonbud, gunting, kaca objek, kaca penutup, botol timbang, pipet tetes, kertas perkamen, lemari pengering, mortar dan stamfer, neraca analitis, neraca halus, pinset, pisau cukur, silet, pot plastik, rotary evaporator, spatula, kertas saring.

Bahan yang digunakan meliputi etanol 96\%, air suling, Betadine salep (PT. Mahakam Beta Farma), estesia krim (PT. Pharmacore), vaseline album, adeps lanae, kalium iodida, iodium, besi (III) klorida, asam klorida $2 \mathrm{~N}$, kloralhidrat, Natrium 
hidroksida $2 \mathrm{~N}$, timbal asetat, $0,4 \mathrm{~N}$, bismut (III) nitrat, air suling, kloroform dan asam sulfat pekat.

\section{Hewan Uji}

Hewan yang digunakan dalam penelitian ini adalah tikus jantan putih 25 ekor, bobot 250-300 gram dengan usia sekitar 2-3 bulan. Tikus ini sebelumnya sudah diaklimasi selama seminggu. Tikus dipelihara dalam kandang diberi sekam. Tikus diberi makan dan minum sesuai dengan kebutuhannya. Yang diperoleh dari fakultas Farmasi Universitas Sumatera Utara. Besar sampel ideal menurut hitungan Rumus Federer adalah 5 ekor tikus putih atau lebih (Zakiah, et.al., 2017). Dengan demikian jumlah tikus putih semua kelompok uji secara keseluruhan adalah 25 ekor, dimana 25 ekor tikus putih tersebut dibagi menjadi 5 kelompok uji, yang masing-masing kelompok uji terdiri dari 5 ekor tikus putih.

\section{Pembuatan Simplisia}

Sampel yang digunakan pada penelitian ini adalah buah kecombrang yang masih segar. Buah dipisahkan dari pengotoran lalu dicuci hingga bersih pada air mengalir, buah ditiriskan dan diangin-anginkan, lalu buah diiris tipis-tipis. Kemudian dikeringkan pada suhu $40^{\circ}$ C. Buah dianggap kering bilang buah sudah tampak kisut dan sudah rapuh. Simplisia yang telah dikeringkan dihaluskan menjadi serbuk lalu dimasukkan ke dalam wadah plastik bertutup (Kemenkes RI, 2017).

\section{Pembuatan Ekstrak}

Serbuk simplisia diekstraksi dengan cara maserasi menggunakan pelarut etanol 96\%. Masukkan satu bagian serbuk kering simplisia ke dalam maserator, tambahkan sepuluh bagian pelarut. Rendam selama 6 jam pertama sambil sesekali diaduk, kemudian diamkan selama $18 \mathrm{jam}$. Pisahkan maserat dengan filtrasi. Ulangi proses penyarian sekurang-kurangnya satu kali dengan jenis pelarut yang sama dan jumlah pelarut sebanyak setengah kali jumlah pelarut pada penyarian pertama. Kumpulkan semua maserat kemudian uapkan dengan rotary evaporator hingga diperoleh ekstrak kental (Kemenkes RI, 2017).

\section{Skrining Fitokimia}

Skrining fitokimia dilakukan di laboratorium Fakultas Farmasi dan Ilmu Kesehatan, Universitas Sari Mutiara Indonesia. Skrining fitokimia simplisia buah kecombrang meliputi pemeriksaan senyawa alkaloid, saponin, flavonoid, tanin, glikosida, dan steroid/triterpenoida (Kemenkes RI, 2017).

\section{Pemeriksaan alkaloida}

Sebanyak 0,5 gram serbuk simplisia ditambahkan $1 \mathrm{ml}$ asam klorida $2 \mathrm{~N}$ dan 90 $\mathrm{ml}$ air suling, dipanaskan di atas penangas air selama 2 menit. Setelah dingin lalu disaring dan filtrat digunakan untuk percobaan berikut:

a. filtrat sebanyak 3 tetes ditambahkan 2 tetes larutan pereaksi Mayer akan terbentuk endapan berwarna putih atau kuning menunjukkan reaksi positif;

b. filtrat sebanyak 3 tetes ditambahkan 2 tetes larutan pereaksi Bouchardat akan terbentuk endapan berwarna coklat-hitam menunjukkan reaksi positif;

c. filtrat sebanyak 3 tetes ditambahkan 2 tetes larutan pereaksi Dragendorff akan terbentuk endapan berwarna merah atau jingga menunjukkan reaksi positif.

alkaloida dinyatakan positif jika terjadi endapan atau paling sedikit dua atau tiga dari percobaan di atas (Ditjen POM., 1995). 


\section{Pemeriksaan flavonoida}

Sebanyak 0,5 gram serbuk simplisia disari dengan $10 \mathrm{ml}$ metanol lalu direfluks selama 10 menit, disaring panas-panas melalui kertas saring berlipat, filtrat diencerkan dengan 10 $\mathrm{ml}$ air suling. Setelah dingin ditambah $5 \mathrm{ml}$ eter minyak tanah, dikocok hati-hati, didiamkan. Lapisan metanol diambil, diuapkan pada temperatur $40^{\circ} \mathrm{C}$. Sisa dilarutkan dalam $5 \mathrm{ml}$ etil asetat, disaring. cara percobaan:

a. Sebanyak $1 \mathrm{ml}$ larutan percobaan diuapkan hingga kering, sisanya dilarutkan dalam 1-2 ml etanol 96\%, ditambahkan 0,5 gram serbuk seng dan $2 \mathrm{ml}$ asam klorida $2 \mathrm{~N}$, didiamkan selama satu menit. Ditambahkan $10 \mathrm{ml}$ asam klorida pekat, jika dalam waktu 2-5 menit terjadi warna merah intensif menunjukkan adanya flavonoida (glikosida-3-flavonol).

b. Sebanyak $1 \mathrm{ml}$ larutan percobaan diuapkan hingga kering, sisanya dilarutkan dalam $1 \mathrm{lml}$ etanol 96\%, ditambahkan 0,1 gram magnesium dan $10 \mathrm{ml}$ asam klorida pekat, terjadi warna merah jingga sampai merah ungu menunjukkan adanya flavonoida (Ditjen POM., 1995).

\section{Pemeriksaan tanin}

Sebanyak 0,5 gram serbuk simplisia disari dengan $10 \mathrm{ml}$ air suling lalu disaring. Filtratnya diencerkan dengan air suling sampai tidak berwarna. Ke dalam $2 \mathrm{ml}$ filtrat ditambahkan 1-2 tetes larutan besi (III) klorida. Jika terjadi warna biru atau hijau kehitaman menunjukkan adanya tanin (Farnsworth, 1966).

\section{Pemeriksaan glikosida}

Sebanyak 3 gram serbuk simplisia disari dengan $30 \mathrm{ml}$ campuran 7 bagian volume etanol $96 \%$ dan 3 bagian volume air suling. Selanjutnya ditambahkan $10 \mathrm{lml} \mathrm{HCl}$ $2 \mathrm{~N}$, direfluks selama 10 menit, didinginkan dan disaring. Pada $30 \mathrm{ml}$ filtrat ditambahkan $25 \mathrm{ml}$ air suling dan $25 \mathrm{ml}$ timbal (II) asetat $0,4 \mathrm{M}$, dikocok, didiamkan selama 5 menit lalu disaring. Filtrat disari sebanyak 3 kali, tiap kali dengan $20 \mathrm{ml}$ campuran 3 bagian volume kloroform dan 2 bagian volume isopropanol. Lapisan air diambil kemudian ditambahkan $2 \mathrm{ml}$ air dan 5 tetes pereaksi Molisch, ditambahkan hati-hati $2 \mathrm{ml}$ asam sulfat pekat. Jika terbentuk cincin warna ungu pada batas kedua cairan menunjukkan adanya ikatan gula (Ditjen POM., 1995).

\section{Pemeriksaan saponin}

Sebanyak 0,5 gram serbuk simplisia dimasukkan ke dalam tabung reaksi dan ditambahkan $10 \mathrm{ml}$ air suling panas, didinginkan kemudian dikocok kuat-kuat selama 10 detik. Timbulnya busa yang mantap setinggi $1-10 \mathrm{~cm}$ tidak kurang dari 10 menit yang tidak hilang dengan penambahan 1 tetes larutan asam klorida $2 \mathrm{~N}$ menunjukkan adanya saponin (Ditjen POM., 1995).

\section{Pemeriksaan steroida/ triterpenoida}

Sebanyak 1 gram serbuk simplisia dimaserasi dengan $20 \mathrm{ml}$ eter selama 2 jam, lalu disaring. Filtrat diuapkan dalam cawan penguap. Sisa dalam cawan penguap ditambahkan 2 tetes asam asetat anhidrida dan 1 tetes asam sulfat pekat. Timbulnya warna ungu atau merah kemudian berubah menjadi hijau biru menunjukkan adanya steroida/triterpenoida (Harborne, 1987). 


\section{Pembuatan Sediaan Salep}

Pembuatan standar dasar salep yang digunakan (Agoes, 2006):

\section{$\mathrm{R} /$}

$\begin{array}{ll}\text { Adeps Lanae } & 15 \text { gram } \\ \text { Vaselin Album } & 85 \text { gram } \\ \text { m.f salep } & 100 \text { gram }\end{array}$

Proses pembuatan salep ekstrak etanol buah kecombrang menggunakan basis adeps lanae dan vaselin album, pemilihan basis salep berlemak yaitu campuran adeps lanae dan vaselin album yang dapat menarik lebih banyak air sehingga luka cepat kering, tidak membusuk, dan menutupi luka (Soegihardjo, 2013).

Cara pembuatannya, pertama siapkan alat dan bahan kemudian timbanglah basis salep sesuai dengan formula salep yaitu 15 gram adeps lanae dan 85 gram vaseline album kemudian dilebur di penangas air sambil sesekali diaduk hingga homogen, lalu tunggu beberapa saat, kemudian dimasukkan ke dalam lumpang, ekstrak kental buah kecombrang yang telah ditimbang ditambahkan pada masing-masing basis salep kemudian digerus di dalam lumpang hingga homogen dan disimpan di dalam pot plastik serta diberi label.

Sediaan formula salep yang akan digunakan pada penelitian ini memiliki masingmasing konsentrasi ekstrak buah kecombrang yaitu 8\%, 10\%, 12\% dibuat sebanyak 30 gram (Eriadi, A., et.al., 2015).

Formulasi salep ekstrak etanol buah kecombrang $8 \%$

$\mathrm{R} /$

$\begin{array}{ll}\text { Ekstrak buah kecombrang } & 2,4 \text { gram } \\ \text { Dasar salep } & 27,6 \text { gram } \\ \text { m.f salep } & 30 \text { gram }\end{array}$

Formulasi salep ekstrak etanol buah kecombrang $10 \%$

R/ Ekstrak buah kecombrang 3 gram

Dasar salep 27 gram

m.f salep 30 gram

Formulasi salep ekstrak etanol buah kecombrang $12 \%$

R/ Ekstrak buah kecombrang 3,6 gram

Dasar salep $\quad 16,4$ gram

m.f salep 30 gram

\section{Evaluasi Sediaan Salep}

Evaluasi sediaan salep mencakup pemeriksaan organoleptik dan homogenitas (Novita, R., et.al., 2017).

\section{Pemeriksaan Organoleptik}

Pemeriksaan organoleptik meliputi bentuk, warna, dan bau yang diamati secara visual. Sediaan dinyatakan stabil apabila warna, bau dan penampilan tidak berubah secara visual selama penyimpanan. Parameter kualitas salep yang baik adalah bentuk sediaan setengah padat, salap berbau khas ekstrak yang digunakan dan berwarna seperti ekstrak (Novita, R., et.al., 2017).

\section{Pemeriksaan Homogenitas}

Uji homogenitas dilakukan dengan menggunakan kaca objek, sejumlah tertentu sediaan jika diletakkan pada sekeping kaca atau bahan transparan lain yang cocok, sediaan harus menunjukkan susunan yang homogen (Novita, R., et.al., 2017). 


\section{Pengujian Salep Terhadap Penyembuhan Luka}

Pada setiap kelompok diberikan perlakuan sebagai berikut:

Kelompok 1 : Luka sayat yang diberi basis salep (kontrol negatif).

Kelompok 2 : Luka sayat diberi salep Betadine ${ }^{\circledR} 10 \%$ (kontrol positif).

Kelompok 3 : Luka sayat ditutupi salep ekstrak etanol buah kecombrang 8\%.

Kelompok 4 : Luka sayat ditutupi salep ekstrak buah etanol kecombrang $10 \%$.

Kelompok 5 : Luka sayat ditutupi salep ekstrak etanol buah kecombrang $12 \%$.

Cukur bulu tikus pada bagian punggungnya, ditandai punggung tikus dengan pola lingkaran berdiameter 4-5 cm. Tikus dianestesi biasanya dengan Estesia ${ }^{\circledR} \mathrm{krim}$, kemudian dibuat luka dengan dibersihkan pakai kapas yang mengandung alkohol $70 \%$. Buat luka dengan menyayat kulit tikus menggunakan pisau silet yang sudah steril (bilas dengan alkohol 70\%) untuk membuat luka dengan kedalaman $2 \mathrm{~mm}$. Pada kulit yang dilukai oleskan salep secukupnya, 2 kali sehari. Pengukuran panjang jangka sorong dilakukan setiap hari (Rizki, et.al., 2019). Parameter yang dipakai dalam penentuan kesembuhan luka adalah penurunan luas dan hari kesembuhan. Luka dianggap sembuh jika diameter luka sama dengan nol.

\section{Analisa Data}

Data hasil penelitian dianalisis dengan metode analisis variasi (ANOVA) dengan tingkat kepercayaan $95 \%$ dan dilanjutkan dengan uji Tukey HSD untuk melihat perbedaan nyata antara perlakuan. Analisis statistik ini menggunakan program versi SPSS.

\section{HASIL DAN PEMBAHASAN}

\section{Hasil Skrining Fitokimia Ekstrak Etanol Buah Kecombrang}

Hasil skrining fitokimia ekstrak etanol buah kecombrang dapat dilihat pada Tabel 1. Berikut ini:

Tabel 1. Hasil skrining fitokimia ekstrak etanol buah kecombrang

\begin{tabular}{|c|c|c|}
\hline No. & Pemeriksaan & Hasil \\
\hline 1 & Alkaloid & + \\
\hline 2 & Flavonoid & + \\
\hline 3 & Saponin & + \\
\hline 4 & Tanin & + \\
\hline 5 & Glikosida & + \\
\hline 6 & Steroid/Triterpenoid & + \\
\hline
\end{tabular}

Keterangan : $+=$ mengandung golongan senyawa

- = tidak mengandung golongan senyawa

Berdasarkan Tabel 1. dapat dilihat bahwa hasil skrining fitokimia menunjukkan ekstrak etanol buah kecombrang positif mengandung senyawa alkaloid, flavonoid, saponin, tanin, glikosida dan steroid/triterpenoid.

\section{Hasil Pembuatan Sediaan Salep Ekstrak Etanol Buah Kecombrang (EEBK)}

Basis salep : 30 gram basis (pada setiap konsentrasi EEBK)

EEKJ $8 \%: 2,4$ gram ekstrak etanol buah kecombrang dalam 30 gram sediaan salep.

EEKJ 10\% : 3 gram ekstrak etanol buah kecombrang dalam 30 gram sediaan salep

EEKJ 12\% : 3,6 gram ekstrak etanol buah kecombrang dalam 30 gram sediaan salep. 
Berdasarkan pengamatan organoleptik, penggunaan sediaan EEBK dalam bentuk sediaan salep sangat efektif karena bahan obat dapat larut atau homogen dengan baik pada basis salep, sehingga dapat dioleskan dengan baik dan dapat menutup luka secara merata, walaupun basis salep berpengaruh terhadap warna sediaan salep tetapi tidak berpengaruh pada bau dari sediaan tersebut. Bau dari sediaan salep EEBK adalah bau khas dari ekstrak buah kecombrang.

\section{Hasil Uji Efektivitas Penyembuhan Luka Sayat}

Pengujian efektivitas penyembuhan luka sayat dilakukan berdasarkan metode Hajiaghaalipour, et.al., 2013. Pengamatan pengujian efektivitas penyembuhan luka sayat dilakukan 1 kali sehari secara visual. Pada penelitian ini jenis luka yang digunakan adalah luka stadium II, luka partial thickness: yaitu hilangnya lapisan epidermis dan bagian atas, dari keterangan: perlakuan 1: diberi basis salep (kontrol negatif), perlakuan 2: perlakuan 2: diberi Betadine salep $10(\%)$ b/b, perlakuan 3: diberi salep EEBK $8 \%$ b/b, perlakuan 4: diberi salep EEBK 10\% b/b, dan perlakuan 5: diberi salep EEBK 12\% b/b.

Kelompok tikus yang paling cepat menyembuhkan luka sayat adalah kelompok sediaan salep EEBK $12 \%$ dan sediaan Betadine salep 10\% pada hari 10 diameter luka sudah sembuh. Kelompok tikus yang diberi salep EEBK 8\% memiliki waktu kesembuhan yang sama yaitu pada hari ke-14. Kelompok yang diberi salep $10 \%$ memiliki waktu kesembuhan pada hari ke-11 sedangkan kontrol negatif tidak memberikan kesembuhan sampai hari ke-14. Hasil pengamatan menunjukkan pemberian sediaan salep EEBK 12\% dalam penyembuhan luka sebanding dengan kontrol Betadine salep 10\%.

Betadine salep dapat menyembuhkan luka sayat karena Betadine mengandung bahan aktif povidon iodin yang mampu menyembuhkan infeksi luka di kulit yang disebabkan oleh bakteri (Gennaro, 2000). Povidon iodin juga dapat menginduksi angiogenesis (pembentukan pembuluh darah baru) dalam penyembuhan luka (Angel, et.al., 2008; Balin, et.al., 2002), tetapi proses epitelisasi yang disebabkan povidon iodin berlangsung lambat (Angel, et.al., 2008; Abbas, et.al., 2015) sedangkan efektivitas sediaan salep EEBK dalam mempercepat penyembuhan luka sayat dikarenakan adanya kandungan tanin yang bertindak sebagai astringen dan antimikroba serta meningkatkan laju epitelisasi, tanin sebagai astringen yang mampu menciutkan pori-pori kulit, antimikroba, antioksidan (Arun, et.al., 2013) dan meningkatkan pembentukan pembuluh kapiler dan fibroblas (Choudhary, 2011), saponin bertindak sebagai antioksidan, antimikroba, meningkatkan laju epitelisasi dan memacu pembentukan kolagen yang berperan dalam proses penyembuhan luka (Arun, et.al., 2013; Mappa, et.al., 2013), dan flavonoid bersifat anti inflamasi karena kemampuannya mencegah oksidasi. Flavonoid juga dapat menyebabkan rusaknya susunan perubahan mekanisme permeabilitas dari dinding sel bakteri yang ada pada luka dan memiliki aktivitas biologis seperti antioksidan (Eriadi, A., et.al., 2015).

Aktivitas farmakologi yang dibutuhkan dalam penyembuhan luka adalah antiinflamasi, antimikroba, antioksidan, analgesik dan astringen. Antiinflamasi diperlukan untuk mencegah terjadinya respons inflamasi yang berkepanjangan pada luka seperti radang, nyeri. Antimikroba untuk menghambat pertumbuhan mikroba yang dapat menyebabkan infeksi sehingga memperlambat proses penyembuhan luka. Antioksidan untuk menangkap radikal bebas yang dapat merusak protein, kolagen yang dibutuhkan dalam penyembuhan luka. Analgesik untuk mengurangi rasa nyeri yang disebabkan oleh luka. Astringen untuk menciutkan pori-pori kulit sehingga pendarahan pada luka dapat berhenti dengan cepat dan luka cepat mengering (Arun, et.al., 2013).

Penggunaan salep EEBK $12 \%$ memiliki efek penyembuhan sebanding dengan kontrol Betadine salep $10 \%$ dan pada kontrol negatif pengurangan diameter luka 
berangsur lambat karena tidak ada zat berkhasiat dalam basis salep yang digunakan sebagai bahan pembawa.

Data panjang luka $(\mathrm{cm})$ pada masing-masing hewan uji pada tiap perlakuan dianalisis secara statistik dengan metode ANOVA lalu dilanjutkan dengan uji Post Hoc Tukey HSD untuk melihat perbedaan nyata dari setiap perlakuan tikus putih. Hasil pengujian ANOVA menunjukkan bahwa terdapat perbedaan yang signifikan $(\alpha \leq 0,05)$ terhadap penyembuhan luka sayat pada hari ke-1 hingga hari ke-15 dengan sig. 0,046 berarti terdapat perbedaan yang signifikan antar perlakuan.

Tabel 2. Pengurangan luka sayat

\begin{tabular}{lccccc}
\hline ANOVA & \multicolumn{1}{c}{ Sum of } & Mean & F & Sig. \\
\hline Squares & Square & df & 010 & 2,936 &, 046 \\
\hline Between Groups &, 042 & 4 &, 004 & & \\
\hline Within Groups &, 071 & 20 & & & \\
\hline Total &, 113 & 24 & & & \\
\hline
\end{tabular}

Adapun perbedaan mana antar perlakuan dapat di lihat pada pengujian Post Hoc Tukey HSD dilakukan untuk melihat kelompok perlakuan mana yang memiliki efek sama atau berbeda dan efek terkecil sampai terbesar antara satu dengan yang lainnya. Pengujian ini dilakukan terhadap semua perlakuan dari hari ke-1 sampai ke-15. Hasil pengujian Post Hoc Tukey HSD menunjukkan bahwa kelompok yang diberi sediaan salep EEBK 8\%, $10 \%, 12 \%$ dan kontrol positif memiliki perbedaan yang signifikan dengan kelompok kontrol negatif. Kelompok sediaan salep EEBK12\% tidak berbeda signifikan dengan kelompok kontrol positif dimana kedua kelompok tersebut terletak dalam satu subset dengan nilai sig 0,8209 mulai hari ke-1 sampai hari ke-10. Hasil menunjukkan bahwa EEBK mampu menyembuhkan luka pada konsentrasi $8 \%$ - 15\%, pengurangan panjang luka terjadi secara bertahap dan semakin tinggi konsentrasi ekstrak efek penyembuhan luka semakin besar, hal ini sejalan dengan penelitian sejenis sebelumnya yang telah dilakukan oleh Gemy et.al., 2015 yaitu penyembuhan luka sayat ekstrak etanol daun kecombrang (Etlingera Elatior Jack) terhadap kelinci ekstrak dengan konsentrasi tertinggi memberikan penyembuhan luka lebih signifikan.

\section{KESIMPULAN}

Berdasarkan hasil penelitian yang dilakukan dapat disimpulkan bahwa sediaan salep ekstrak etanol buah kecombrang efektif terhadap penyembuhan luka sayat pada tikus putih. Ekstrak etanol buah kecombrang dengan dosis yang terbaik pada konsentrasi $12 \%$. karena pada konsentrasi $12 \%$ paling efektif dalam mempercepat proses penyembuhan luka sayat pada tikus putih dibandingkan dengan ekstrak etanol buah kecombrang konsentrasi $10 \%$ dan ekstrak etanol konsentrasi $8 \%$ yang memiliki waktu penyembuhan yang sama dengan kontrol positif (Betadine salep).

\section{REFERENSI}

Abbas, O.L., Borman, H., Bahar, T., Ertas, N.M., \& Haberal, M. (2015). An In Vivo Comparison of Commonly Used Topical Antimicrobials on Skin Graft Healing After Full-Thickness Burn Injury. Journal of Burn Care \& Research. 36(2): 47-54. https://doi.org/10.1097/BCR.0000000000000072. 
Agoes, G. 2006. Pengembangan Sediaan Farmasi. Hal 207-217. Penerbit ITB. Bandung. Angel, D.E., Morey, P., Storer, J.G., \& Mwipatayi, B.P. (2008). The great debate over iodine in wound care continues: a review of the literature. Wound practice and Research. 16(1): 6-21. 1 Retrieved https://www.awma.com.au/files/journal/1601_01.pdf.

Arun, M., Satish, S., \& Anima, P. (2013). Herbal Boon for Wounds. International Journal of Pharmacy and Pharmaceutical Sciences. 5(2): 1-12. Retrieved from https://www.researchgate.net/publication/285919149_Herbal_boon_for_wounds

Balin, A.K., \& Pratt, L. (2002). Dilute Povidone Iodine-Solutions Inhibit Human Skin Firoblast Growth. Dermatologic Surgery. 28(3): 210-214. https://onlinelibrary.wiley.com/doi/abs/10.1046/j.1524-4725.2002.01161.x

Choudhary, G.P. (2011). Wound Healing Activity Of The Ethanolic Extract Of Terminalia chebula Retz. International Journal of Pharma and Bio Sciences. 2(1): 48-52. Retrieved from https://www.researchgate.net/journal/InternationalJournal-of-Pharma-and-Bio-Sciences-0975-6299.

Direktorat Jenderal Pengawasan Obat dan Makanan. (1995). Farmakope Indonesia. Edisi IV. Jakarta: Departemen Kesehatan RI. Halaman 1030-1031.

Eriadi, A., Arifin, H., Rizal, Z \& Barmitoni. (2015). Pengaruh Ekstrak Etanol Daun Binahong (Anredera cordifolia (Tenore) Steen) Terhadap Penyembuhan Luka Sayat Pada Tikus Putih Jantan. Jurnal Farmasi Higea. 7(2): 162-173. Retrieved from https://www.jurnalfarmasihigea.org/index.php/higea/article/viewFile/127/123

Farnsworth, N.R. (1966). Biological and phytochemical screening of plants. J Pharm Sci. 55(3): 99; 225-276. Retrieved from https://jpharmsci.org/article/S00223549(15)35305-3/pdf.

Gennaro, R.A. (2000). Remington: The Science and Practice of Pharmacy Edition 20th. New York: Lippincot Williams \& Wilkins. Halaman 1629.

Gemy N. Mukhirani. Rezkiyana M. 2015. Uji Penyembuhan Luka Sayat Ekstrak Etanol Daun Kecombrang (Etlingera Elatior) Dalam Sedian Gel Terhadap Kelinci (Oryctolagus Ciniculus). Makassar: Univesitas Islam Negeri Alauddin. 3:54-55. Retrieved from http://journal.uinalauddin.ac.id/index.php/jurnal_farmasi/article/ view/2206/2137.

Hajiaghaalipour, F., Kanthimathi, M. S., Abdulla, M. A., \& Junedah, S. 2013. The Effect of Camellia sinensis on Wound Healing Potential in an Animal Model. EvidenceBased Complementary and Alternative Medicine. 7: 1-8. Retrieved from https://www.hindawi.com/journals/ecam/2013/386734/.

Harborne, J.B. (1987). Metode F itokimia. Penerjemah: Kosasih Padmawinata dan Iwang Soediro. Edisi II. Bandung: Penerbit ITB. Halaman 102-103, 152.

Kementerian Kesehatan RI. 2017. Farmakope Herbal Indonesia Edisi II. Jakarta: Kementerian Kesehatan RI.

Mappa, T., Edy, H.J., \& Kojong, N. (2013). Formulasi Gel Ekstrak Daun Sasaladahan (Peperomia Pellucida (L.) H.B.K) Dan Uji Efektivitasnya Terhadap Luka Bakar Pada Kelinci (Oryctolagus Cuniculus). Pharmacon Jurnal Ilmiah Farmasi. 2(2): 52. https://doi.org/10.35799/pha.2.2013.1606.

Novita, R., Munira \& Hayati, R. 2017. Formulasi Sediaan Salep Ekstrak Etanol Pliek U Sebagai Antibakteri, Jurnal AcTion: Aceh Nutrition Journal. 2(2): 103-108. Retrieved from http://ejournal.poltekkesaceh.ac.id/index.php/an/article/view/62/41

Rizki P. Nusdianto T., \& Maya N. 2019. Efektivitas Ekstrak Daun Afrika (Vernonia) Secara Topikal Untuk Repitelisasi Penyembuhan Lka Isisim Pada Tikus Putih (Rattus Norvegiku). Jurnal Medik Veteriner. 2:34. Retrieved from http://dx.doi.org/10.20473/jmv. vol2.iss1.2019.30-35. 
Soegihardjo, C.J. 2013. Farmakonogsi. Klaten: Intan Sejati.

Zakiah, N., Yanuarman, Frengki, dan Munazar. (2017). Aktifitas Hepatoprotektif Ekstrak Etanol Daun Sirsak (Annona Muricata L.) Terhadap Kerusakan Hati Tikus Yang Diinduksi Dengan Parasetamol. Jurnal AcTion: Aceh Nutrition Journal. 2(1): 25-3. Retrieved from http://ejournal.poltekkesaceh.ac.id/index.php/an/article/view/33. 